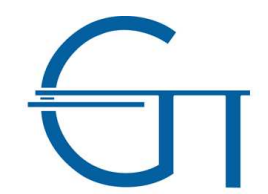

The Hellenic Observatory

The European Institute

\title{
A new role for the church? \\ Reassessing the place of religion in the Greek public sphere
}

Effie Fokas

GreeSE Paper No 17

Hellenic Observatory Papers on Greece and Southeast Europe

August 2008 


\section{Table of Contents}

ABSTRACT_

1. Introduction __ 1

2. A 'master' narrative on Orthodoxy, Greek and beyond ___ 3

3. The Greek historical and political context ___ 8

3.1. Historical contingencies in the religion-national identity link ___ 9

3.2. Legal framework of church-state relations ___ 13

3.3 Agency - 1998-2008___ 23

4. Reassessing the place of religion in the Greek public sphere __ 29

5. Conclusion _ 35

\section{Acknowledgements}

This paper was completed during my time as Laskarides Research Fellow at the Hellenic Observatory; I am grateful to the Laskaridis Foundation for their generous support. I would also like to thank Grace Davie, Kevin Featherstone, Fr. Alexander Fostiropoulos, Fr. Leonid Kishkovsky, Nikos Kokosalakis and David Martin for their helpful comments on this text. 
A new role for the church?

\title{
Reassessing the place of religion in the Greek public sphere
}

\author{
Effie Fokas ${ }^{\#}$
}

\begin{abstract}
This title is borrowed from a 1999 article by Nicos Alivizatos, in which he considered whether the election of Archbishop Christodoulos ushered in a new role for the church vis-à-vis the Greek state. Ten years on, in the aftermath of the election of a new archbishop - Ieronymos - it seems fitting to revisit the question and, in so doing, to reassess the place of religion in the Greek public sphere.
\end{abstract}

Keywords: religion and national identity; church-state relations; agency and transition; public sphere.

\footnotetext{
\# Visiting Research Fellow in the European Institute, London School of Economics. Correspondence: Effie Fokas, Patroklou 22, Vrilissia 15235, Athens, Greece. Email: e.s.fokas@1se.ac.uk
} 



\section{A new role for the church?}

\section{Reassessing the place of religion in the Greek public sphere}

\section{Introduction}

The Orthodox Church of Greece under the leadership of Christodoulos fit many of the stereotypes facing Greek Orthodoxy, and the Orthodox world in general: namely, a politicised, nationalist-tending church, and one which actively protects privileges it enjoys vis-à-vis the state (enjoyed at the expense of minority faiths) ${ }^{1}$. These stereotypes tend to carry assumptions about the nature of the Orthodox faith and, specifically, about 'organic' links between religion and national identity, and between church and state in Orthodox contexts. However, such perspectives fail to account for contingencies, variations and differentiations throughout ecclesiastical history in the Orthodox world and, indeed, in modern Greece. They also fail to account for changes ushered in by Archbishop Ieronymos, elected for the role in February 2008. The relevant literature lacks a systematic study of the range of factors at play across various Orthodox contexts, including agency (political and religious), historical context, and the legal framework of church-state relations - a large project critically needed within individual Orthodox country cases, and across cases.

\footnotetext{
${ }^{1}$ 'Church' in this text refers to an institutional body rather than a body of believers.
} 
The present study is limited to the case of Greece but will bear resonance for other Orthodox contexts also. In the pages that follow, I will offer as a backdrop to our examination certain representations of the Orthodox world which echo prevalent stereotypes. I will then narrow the focus to the Greek case, challenging conceptions of organic links between religion and national identity, and between church and state, by exploring three interrelated dimensions in particular: historical contingency in the development of the relationship between religion and national identity; the specificities of churchstate relations in the Greek case; and the factor of agency, touching on the transition in the Archbishopric from Christodoulos to Ieronymos.

Finally, I will bring these strands together in a discussion on the place of religion in the Greek public sphere, including debates on church-state relations particularly in the aftermath of Ieronymos' election. Here I will, necessarily, rely heavily on newspaper coverage during a limited time period.

The timing for such an exercise is ripe, not only because of the change in church leadership, but also because of the debates about the place of religion in the European public sphere currently taking place. The idea is to move the discussion on the Greek case further: rather than stagnating in accounts of Orthodox or Greek exceptionalism which highlight differences from other Christian contexts, to examine instead common contributions to a broader discussion on religion in the public sphere. This paper thus aims to steer clear of essentialised assumptions about the nature of the faith in relation to 
nationalism and church-state relations and to focus attention, instead, on what are indeed operative factors in these 'problem areas' identified in many Orthodox contexts.

\section{A 'master' narrative on Orthodoxy, Greek and beyond}

Christian Orthodoxy is amongst the most obscured presences on the European religious scene. In spite of the inclusion of large Orthodox populations in the European Union with the last waves of EU expansion, awareness of Orthodoxy in its multiple expressions remains fairly clouded and/or undeveloped beyond its borders. There are of course several seemingly logical reasons for this, including the lack of a unified representative voice comparable to the Roman Catholic Pope (and, in its stead, a large number of national churches), as well as the fact that much of the Orthodox population now part of the EU was, until relatively recently, under Communist rule. Meanwhile, the faith's emphasis on mystery, ritual etc., may also render it less conducive to easy comprehension from an external (and internal, for that matter) perspective (Vassiliadis 2003). Certainly there is a sense of strong difference from Western Christianity which, for some, rightfully awards Orthodoxy's placing in Samuel Huntington's civilizational divides. These differences are generally explained with reference to the fact that the Orthodox world did not experience the Renaissance or the Enlightenment but, rather, centuries of Ottoman rule, and the fact of Communist rule for generations of Orthodox peoples, which led to 
underdevelopment (especially in terms of democratic mindset) in many European Orthodox contexts.

These generalized conceptions are buttressed by the existence of multiple offices representing Orthodoxy in Brussels rather than one voice unified under the Ecumenical Patriarchate, as well as by events in the Orthodox world which have received international press coverage. For example: the Greek Orthodox Church's resistance to a visit by the Pope in 2001; the subsequent tensions between it and the Ecumenical Patriarchate beginning in 2003 which led to Archbishop Christodoulos' temporary status of being 'out of communion' with the Ecumenical Patriarchate; and the tension between the Orthodox Church of Macedonia and, in particular, the Orthodox Church of Serbia, especially over the latter's refusal to recognize the autocephaly of the former. Other events from the Orthodox world which reach the international press are likewise damning, though different in nature: a case in point is the Jerusalem Patriarchate's controversial sale of lands to the Israeli state (2005), in exchange for the latter's recognition of the newly elected Orthodox Patriarch of Jerusalem. Indeed, media representations often reflect what Richard Clogg describes as 'casual but damaging ignorance... which will have been read by tens, perhaps hundreds, of thousands of readers' (Clogg 2002: x).

Meanwhile, academic literature on Orthodoxy too is often characterised by an explicit focus on such trends. For example, in an edited volume on Religion in an Expanding Europe, one scholar writes: 
Orthodoxy, thus, is a religion which - to quote Shakespeare - 'looks on tempests and is never shaken' - not even when it should be. Whatever changes may impact the world, the Orthodox Church refuses, for the most part, to accommodate itself to change, standing fixed in time, its bishops' gaze riveted on an 'idyllic past' which serves as their beacon (Ramet 2006: 148).

The article makes the broader argument that Orthodoxy generally carries a mistrust of liberalism, cosmopolitanism, universalism, and democracy. Elsewhere in the same volume, it is suggested that the ties between religion and nation are 'much more pronounced and organic in the Orthodox tradition' (Byrnes 2006: 293). That these ties are relatively pronounced in Orthodox contexts is an anticipated assessment and one applicable to many, though not all, Orthodox settings. To say they are 'organic', though, requires careful analysis.

Indeed, the term 'organic' factors prominently in certain texts on Orthodoxy. What such authors mean by 'organic' is worth considering. The Oxford English Dictionary offers two definitions which fit the predominant uses of the term: a. (of parts of a whole) fitting together in a harmonious way; and b. (of development or change) continuous or natural. Such conceptions of Orthodoxy as 'seamless' and 'timeless' are often taken for granted and embedded in both media and academic literature representations of Orthodoxy. And upon this basis a whole range of conclusions are drawn regarding the various ails of Orthodox societies. For example, one author suggests that 'The centrality and unchanging nature of Orthodox dogma promote anti-intellectualism and racist 
and xenophobic attitudes' (Danopoulos 2004: 51). Focusing on the Greek case, another author argues that 'Greece's organic conception of society embodied in the nation-state and the centrality of Orthodoxy makes accommodation to Europe difficult at best', for Greece is a society 'in which the ethnos, religion and the state constitute an organic whole' (Pollis 1993: 355; see also Payne $2003)^{2}$.

Critically, such perspectives often lack nuance, are sometimes inaccurate and ahistorical, and tend to obscure the real factors at play behind the ails and drawbacks in contemporary Orthodox societies. They need to be qualified, at least, by a consideration of the diversity of Orthodox expression and the historical and political particularities of each Orthodox context. The latter will be explored below with reference to the Greek case.

Regarding the former, a more nuanced approach recognises distinctions between Orthodoxy in the 'heartlands' (i.e., including Russia, Greece, Serbia, Romania, Bulgaria, Macedonia, much of the former USSR), and Orthodoxy in the diaspora. Many Orthodox churches in the United States, for example, operate as hubs of national identity for various diasporic communities (be they Greek, Serbian, Russian, etc., but most often separate churches for separate national communities). In several cases, the congregations of these churches are leading struggles to maintain the liturgies in the national languages regardless of whether a majority, or even a sizable minority - of the members

\footnotetext{
${ }^{2}$ This paper is written from a political sociology (of religion) perspective and not from a theological perspective. But it would be fruitful indeed if texts such as those cited above were analysed from the perspective of Orthodox theology.
} 
of the congregation actually speak the national languages. This struggle is often waged in opposition to converts to Orthodoxy, who often favour a denationalized space for worship (see Kishkovsky 2004). Meanwhile, in yet other contexts the struggle to maintain the nation-religion link is led by the 'mother church' in the Orthodox heartlands.

Even within Europe, further distinctions must be drawn between contexts in which Orthodoxy is the historically dominant faith (where indeed 'nation' and 'religion' tend to overlap); Orthodoxy in western Europe (where 'the Orthodox have formed a small but intellectually vigorous community of émigrés and converts' (Clark 2004; see also Vassiliadis 2003)); and Orthodoxy lived as a minority faith in places such as Finland or Albania, or even Poland (devoid of such religion-nation, church-state links). This diversity of environments in which Orthodoxy operates leads to vastly different constellations of the relationship between religion and nation. In the 'heartlands', the religion-nation link often translates into a special relationship between church and state. This fact introduces an entirely different dynamic, and is accompanied by a range of institutional interests which often drive the churches' efforts to preserve this link. These interests include, but are not limited to, the ownership of large land estates by the church, and the preservation of a privileged position above other faith groups in the given country. It is this latter type of religion-nation, churchstate link which leads to the problem, in many Orthodox contexts, of antipluralist behaviour and discrimination against, as well as barriers to the right to worship, of other faith groups. But, significantly, it doesn’t appear everywhere 
nor equally and as a constant. A more focused examination of the Greek case reinforces this point.

\section{The Greek historical and political context}

A superficial glance into the place of religion in the Greek public sphere would offer an exaggerated image similar to that presented of Orthodoxy in general in the international press and much academic literature: the headline-grabbing events paint a fairly bleak picture, including those already mentioned, but also the coverage of church-state struggle over the identity card issue; the scandals which swept through the church in 2005; and the allegations of the church's involvement in the controversy which rocked the Jerusalem Patriarchate in 2005. A result is a picture of a nationalistic, politicized and corrupt church which is exceptionally incompatible with the norms of European secular neutrality.

But this suggests an inevitability and offers little by way of understanding the actual factors underlying such developments related (directly or indirectly) to Greek Orthodoxy. Instead, what is required is insight into a number of contingencies, including the historically developed relationship between religion and national identity in the Greek case; the particular relationship between church and state that developed (and was constitutionalised) in Greece on the basis of the latter; and the role of agency and, in particular, church leadership. Of course, other dimensions that need to be taken into consideration 
are context, in terms of external developments (national or international) that may influence the church's trajectory, as well as public opinion in these particular contexts. In other words, a range of factors influence the place of religion in the public sphere, each of which requires individual analysis.

In the following paragraphs, the focus is first on the dimensions of the religionnational identity link, looking specifically at climactic points in its historical development; second, on church-state relations, examining the constitutional framework of these, specific aspects leading to limitations of religious freedoms for the non-Orthodox, and patterns in church-state conflict; and third, on agency, taking examples especially from the transition in church leadership from Archbishop Christodoulos to Archbishop Ieronymos in February-March 2008. The interrelatedness of these three dimensions will become especially clear in the section on agency.

\subsection{Historical contingencies in the religion-national identity link}

The historical links between religion and national identity in Greece are broad and deep, and well-researched ${ }^{3}$. It will suffice to highlight, simply for indicative purposes, certain climactic points in the evolution of this relationship in modern Greece. The first is the experience of the Orthodox Church under the Ottoman Empire and, specifically, the role that the experience of the Ottoman

\footnotetext{
${ }^{3}$ A full historical analysis of the relationship between religion and national identity would take us at least as far back in history as the Byzantine Empire and the Great Schism, but space limitations do not allow for such historical depth.
} 
millet system played in consolidating religious and national identity. Under the millet system, non-Muslim communities were divided into religious groups and given 'protected' status: in exchange for the payment of a special tax, they were allowed to live within the Muslim state without converting to Islam, but as second-class subjects. The millets enjoyed a measure of autonomy and were represented by their religious leaders in their dealings with the Sublime Porte. Although the Orthodox millet was ecumenical and multinational in nature, in reality it was largely Greek-dominated: the succession of Patriarchs was Greek, and the social administration was almost exclusively in the hands of Greeks. Accordingly, beyond the institutional role of the church - in its economic, legal, and political dimensions - one must also note the important psychological function it had for the Greeks under Ottoman rule: the church was seen as provider and protector of the people and preserver of their national identity.

Meanwhile, the relative comfort enjoyed by the church in this context meant the high clergy were not entirely supportive of revolutionary ideas which might threaten their relatively privileged positions ${ }^{4}$. (This in spite of textbook presentations of the church as a leader in the revolution: many individual clerics did fight for national independence, but not, it should be noted, the majority of the high clergy). Nor was the establishment of the Autocephalous

\footnotetext{
${ }^{4}$ Besides the aforementioned power and privileges, the church also became especially wealthy: many Orthodox Christians transmitted their land to the church and the monasteries since, under the millet system, ecclesiastical property was protected from confiscation by the Turks.
} 
Church of Greece supported by the church leadership (see Dimitropoulos 2001; Manitakis 2000a and 2000b; Anagnostopoulou 2000).

Significantly, autocephaly was the decision of a (Bavarian and Protestant) three-man regency council of the (Roman Catholic) King Otto who ruled newly independent Greece. It was deemed by the former that political independence also required ecclesiastical independence. The fact that autocephaly was a $\underline{\text { revolutionary }}$ act - i.e. a split from the Patriarchate without the latter's consent - signified the attainment of the fullest extent of national independence and national identity (Anagnostopoulou 2000). According to Thanos Veremis, this is when the state 'incorporated the Church and its martyrs into the pantheon of Greek heroes and made them integral parts of the national myth' (Veremis 1989: 136).

Meanwhile, the declaration of autonomy from the Ecumenical Patriarchate entailed also legalisation of the church's subordination to the state. The administrative leader of the highest ecclesiastical power, a five-member Synod, was to be the King (though Roman Catholic). The latter was in accordance with the Bavarian prototype whereby the King was also the 'supreme bishop' (Kokosalakis 1987: 235); it was not, to be certain, a Byzantine or Orthodox legacy.

A further climactic period in the developing links between Orthodoxy and Greek national identity is to be found in the flourishing of the Megali Idea ('Grand Idea') for redemption of Greek still under Turkish rule outside the 
boundaries of the Greek state. Here the aims of the state for its expansion coincided with the visions of religious nationalists for 'redemption' of Orthodox peoples-visions which were expressed with reference to Byzantine glory. The Megali Idea entailed a clear blending of millenarianism with nationalism, and of Orthodoxy with Greek national identity and acted as an ultimate synthesis of church, state and national identity. It collapsed of course with the defeat of the Greek army in Asia Minor in 1922. As a result of the exchange of populations foreseen by the Lausanne Treaty following the war (1923), Greek society became religiously homogenous (97\% Orthodox).

The 1967-74 military dictatorship ought also to be included as a significant period in the historical relationship between religion and national identity. The junta's 'theocratic-puritanical' government, signified by its motto 'Greece of Christian Greeks', carried inestimable long-term effects on the relationship between the church and national identity. First, the perception that the church serves the interests of the powers that be was strengthened. But of course, the stronger lasting sentiment was that the church did so uncritically, and that it worked in close cooperation with an undemocratic, violent leadership. There lingered in public life, after the 1974 return to democracy, what one scholar describes as 'a kind of repugnance which is usually expressed with the phrase "let the priests destroy themselves".' (Yannaras 1976: 139).

One underlying theme in these historical references spanning centuries is political expediency, in very particular circumstances - circumstances which, 
without too much imagination necessary, one could see how they could have been different, and with different outcomes in terms of the relationship between religion and national identity. Still, the religion-national identity link has shown remarkable resilience - many banal examples of this are to be found below.

\subsection{Legal framework of church-state relations}

The legal-framework for contemporary church-state relations in Greece is set out in the 1975 Constitution that came into effect after the return to democracy. As we shall see, this legal framework leaves considerable room for entanglements between the church and the state; for privileges of the Orthodox Church above (and against) other faith groups; and for certain trends in churchstate conflict. Significantly, church-state relations are very much built and sustained on the foundation of the relationship between religion and national identity.

The 1975 Constitution introduced some notable changes in the domain of church-state relations. First, it removed the requirement that the President of the Republic be Orthodox and take an oath before Parliament promising to 'protect' the Greek Orthodox faith ${ }^{5}$. Furthermore, the clause forbidding proselytism was moved from Article 3 (where the subject of proselytism was treated as a matter of protecting solely the Orthodox Church) to Article 13 on

\footnotetext{
${ }^{5}$ The president's oath no longer pledges protection of the Orthodox faith, but it does make reference to the deity. There is no alternative oath, as is provided for members of Parliament in Article 59 of the 1975 Constitution (See Dimitropoulos 2001: 67).
} 
human rights (thus prohibiting proselytism perpetrated against any faith). The articles of the 1975 Constitution in force today which determine church-state relations are mainly Articles 3,13 and 16. The first affirms recognition of Orthodoxy as the 'prevailing' faith; the second guarantees religious freedoms of conscience and of worship ${ }^{6}$; and the third sets out 'development of religious conscience of youth' as one of the aims of national education. In combination, the three lead to significant entanglements between church and state, to privileges enjoyed by the Orthodox Church at the expense of minority faiths represented in Greece, and to certain patterns in church-state relations.

In terms of entanglements: the clergy of the Orthodox Church of Greece are remunerated and pensioned by the state; the state pays the salaries and pensions of the clergy, pastors and lay employees of the Orthodox Church, and the church is exempted from taxation ${ }^{7}$. State holidays are based on the religious calendar, so that the holidays of the Greek Orthodox Church are acknowledged as official national holidays (well beyond the extent to which this is the norm in other European states - see Konidaris 2003). Further, the Statutory Charter of the church must be passed by the Plenary Session of Parliament; and the Archbishop presides over each opening session of Parliament and blesses with Holy Water each of the parliamentarians. And of especially symbolic impact is

\footnotetext{
${ }^{6}$ Paragraphs 1 and 2, respectively, of Article 13. According to Paragraph 2, 'known' religions are protected by this provision. To be 'known' the religion must not have a secret dogma or a hidden cult; it must apply to the Greek state for recognition; and the cult should not offend public order and moral principles. The latter includes the whole set of civil, moral, social and economic principles and beliefs prevailing in Greek society at a given period. The above conditions are enforced by the public administration and, ultimately, by the courts. See Papastathis (1996: 84).

${ }^{7}$ Certain tax exemptions apply to other faiths as well, while the state receives $35 \%$ of all parish revenues (Papastathis 1996: 86).
} 
the fact that church and state leaders often jointly preside over state functions and national holiday celebrations ${ }^{8}$. Finally, one cannot underestimate the role of politicians themselves in entrenching such church-state links through their own presence and contributions to religious functions ${ }^{9}$. Each of these facts, in varying degrees, entails an especially close relationship between church and state in Greece.

Of particular importance to us here is how some of the privileges of the Orthodox Church vis-à-vis the state entail restrictions on religious freedoms of heterodox citizens and limitations on the principle of equality. These restrictions raise problems with regard to Greece's status as a signatory to the European Charter for Human Rights. There are several domains in which the Orthodox Church enjoys a privileged status over other faiths, but I will limit our focus here to two: the building and operation of places of worship for nonOrthodox peoples in Greece; and the application of legal provisions against proselytism.

In the first case, Greek Orthodox metropolitans (bishops presiding over the 'metropolises' into which the church administration is divided) are given a role in the issuance of licenses for the building of places of worship for minority faiths. It is a 1939 law, enacted under the Metaxas dictatorship, which remains

\footnotetext{
${ }^{8}$ The most obvious example is that National Independence Day, $25^{\text {th }}$ of March, is also not coincidentally a major religious holiday (the annunciation of Mary). It is interesting to note that during one of the most intense church-state conflicts in history (over ecclesiastical property; see below), one of the church hierarchy's most severe reprisals was refusal to be present at the 25 March celebrations.

${ }^{9}$ This is a broad topic for which space limitations do not allow full attention. See Kokosalakis (1987, 1995, 1996, 1997); Stavrou (1995); Demertzis (1996); Georgiadou (1995), esp. pp.307-10; and Paparizos (1998).
} 
in force as determinant of the rights of minority faiths to construct churches and operate places of worship. According to this law, beyond the usual building permit, the construction of any church or place of worship requires an application for permission submitted to the Minister of Education and Religious Affairs who, in turn, seeks the approval of the relevant Greek Orthodox bishop. The application must be signed by 50 families residing in the area. The local bishop is to forward his opinion to the Minister of Education and Religious Affairs on the 'necessity' of such a building (the law states that, for the license, there must be a real need for worship which cannot be satisfied due to the lack of other churches/houses of worship of the same dogma in the geographical area). If a church is built without license, this is punishable with jail and the local metropolitan has the right to call for demolition of the building.

In fact, though, the approval of the local bishop is, in legal terms, an 'opinion' which the Minister of Education and Religious Affairs is required to hear, but not to obey, in deciding on issuance of the permits. However, if a Ministry chooses to permit the establishment against the metropolitan's recommendation, it would have to justify its decision. In practice, the metropolitans are almost always against such developments and the Ministry does not as a rule oppose them (Papastathis 1996: 85). Thus, in reality, the dominant tendency today still gives priority to the safeguarding of the prevailing religion over true religious freedom (Dimitropoulos 2001: 144). Notably, the discriminatory enforcement of this legislation by Greek authorities 
has been the subject matter of a path-breaking case leading to unreserved condemnation of Greece by the European Court of Human Rights for practices against religious minorities (Manoussakis and Others v. Greece, 1996).

The second problematic issue relates to legislation against proselytism. Although the 1975 Constitution extended the law against proselytism to protect all faiths and not solely Orthodoxy, the prevalent tendency is use of this legislation mainly to defend the Orthodox Church against the spread of other faiths in Greece. As in the case of licenses for the building and running of places of worship, the operative legislation on proselytism goes back to the time of the Metaxas dictatorship. The definition of proselytism is set out in a 1939 law as: 'the attempt to intrude on the religious beliefs of a person of a different religious persuasion...by taking advantage of his inexperience, trust, need, low intellect, or naïveté ${ }^{10}$. Especially problematic here is the vague wording of the clause, which has allowed for extremely strict interpretation of non-Orthodox actions. As Alivizatos (1999) notes, the mere distribution of pamphlets and brochures, and the mailing of books and periodicals, have led to prosecution and even to prison sentences.

This too has led to indictments against the Greek state in the ECtHR, most notably in the Kokkinakis v. Greece (1993) case. This case is especially significant, as it is the first ever case to be decided in the European Court in the light of Article 9 of the European Convention on Human Rights (ECHR),

\footnotetext{
${ }^{10}$ Law 1672/1939. See Alivizatos 1999: 30 for the full operative definition of proselytism (the above quotation is an excerpt), and for an analysis of problematic aspects of the definition.
} 
which protects the freedom of thought, conscience and religion. $\mathrm{Mr}$. Kokkinakis, a Greek national who converted to Jehovah's Witnesses, was arrested over sixty times on the charge that he was practicing proselytism. The court condemned the Greek state for infringing on Mr. Kokkinakis' right to religious freedom. At the same time, it ruled that member states have a legitimate interest to prosecute 'improper proselytism' (which, according to Article 9 of the ECHR, is understood as abusive, fraudulent, or employing violent means). Significantly, the court did not declare the Greek law on proselytism incompatible with the European Convention, since the law could also be seen as a means to protect the rights and freedom of others. Thus, although the Greek provision on proselytism is clearly aimed at protecting the social status of the Greek Orthodox Church, and operates this way in practice, the Greek law on proselytism was deemed legitimate, in as much as it applied to 'improper proselytism' (which was not judged to be the case in Kokkinakis) (Martinez-Torron and Navarro-Valls 2004).

It should be clear that in both cases of the legislation on the building places of worship and on proselytism, it is not so much the formal constitutional establishment of the Orthodox Church of Greece as 'prevailing' which is the crux of the problem, nor specific legislation, but the advantages to the Orthodox Church which exist in practice (and, as suggested above, neither has the ECtHR countered this formidable trend). These privileges, as we shall see, continue to exist due to the complex interaction between the religion-national identity link, established patterns in church-state relations, and the political 
impact which results from both of these factors - again, then, a series of contingencies.

Finally, in the domain of church-state conflict: since the 1974 return to democracy there have been three major instances of church-state conflict (and more numerous minor ones than can be listed here): conflict over church property; over changes to the civil code; and over the reference to religious affiliation on the national identity cards. The first of these began in 1985, when a Panhellenic Socialist Movement (PASOK) government came to power after an intense campaign including the revision of church-state relations. Arguing that the state's covering of the whole of the church's functional expenses was a large burden on the state budget, the government proposed reform in the management of church estate and the yielding of part of the vast church property to the state. The then Minister of Education and Religious Affairs Antonis Tritsis introduced laws 1700/1988 on 'the regulation of issue of church estate', and 1811/1988 on 'the yielding of forest and agricultural estates of the monasteries of the Church of Greece to the public'. The plan provoked acute reactions from the church hierarchy, which argued that the provisions were unlawful in their lack of provision of an exchange in favour of the church.

The state offered a counter-proposal, also rejected by the church. The latter took the case to the Greek Supreme Court ('Council of State', StE), which ruled in favour of the state. Finally, following threats from the Archbishop (Seraphim, at the time) that the church would publicly declare itself as 'under 
prosecution', a series of personal meetings between the Archbishop and the Prime Minister yielded a 'temporary' impasse which continues until today. The 1988 law was never fully applied; Minister Tritsis resigned in personal protest; and certain monasteries took their cases to the ECtHR.

Under the same government there was also considerable tension over the state's 'progressive' efforts to reform the civil code. The government introduced legislative change towards equality of the sexes, decriminalisation of adultery, end of the dowry system, etc. One such proposed change was to make civil marriage required; this became a central point of intense struggle between church and state. Again, in this case, the state compromised under pressure from the church, and civil marriage was simply made an option and legally equal to religious marriage. This remained a sore issue, with repeated calls on the part of certain scholars and politicians for reform of marriage laws, and defensive expressions of fear, on the part of the church, that the state might try again to 'get its way' on the matter (Prodromou 1993; Pollis 2003). And in fact it receives new attention, at the time of writing, with debates on a "cohabitation law' introduced in early 2008 by the current New Democracy government (see below).

By far the most potent church-state conflict in recent years was that over the identity cards - beginning in 2000 when the then Prime Minister Simitis announced the planned removal of religious affiliation from the national identity cards. The 'identity card crisis' has been widely studied and analysed, 
from a number of different perspectives (Molokotos-Liederman 2007; Stavrakakis 2003; Fokas 2006). For our purposes, it will suffice to emphasise certain dimensions of the conflict - in particular, the interrelatedness of the three areas of the religion-national identity link; church-state relations and privileges enjoyed by the Orthodox Church of Greece; and the role of agency. Archbishop Christodoulos was very much the protagonist in this issue, from the first moment of criticising the state for taking such a policy decision without consulting the church (i.e., claiming the privilege that the church ought to be consulted on a policy protecting private data in line with a European Union directive).

Christodoulos sought to reverse the decision by gathering signatures to call for a referendum (in spite of the fact that he was told, by the President of the Republic, that a referendum call through such a process would be unconstitutional). In order to gather these signatures, he relied very much on the religion-national identity link by representing the church as a protector of the nation. For example, during the mass protests he declared: 'We will not become grave-diggers of our ethnos. We are more than they who want to destroy the country. The People endorses [sic] what I say. Let there then be a referendum' (Antoniadou 2000a).

Further, the Archbishop maintained that the upcoming prefectural and municipal elections would be held 'in the shadow of the identity card issue', and he called on all political parties to 'honestly inform the electorate what they 
will do after the elections on the identity card issue' ('The identity cards poison' 2002). Christodoulos lost the identity-card battle with the state, in the sense that religious affiliation was, in fact, removed from the new identity cards being printed. But it may be argued that he won the war in the sense that, indeed, to a large extent the elections were held in the shadow of the identity cards, with Christodoulos hinting at church-favoured candidates in his widely publicised sermons, and with candidates of both main parties seeking, in an especially public way, his blessing prior to the elections. This extra soft approach towards the Archbishop extended even to the then Foreign Minister George Papandreou in his consultation with the Archbishop on the Annan Plan for Cyprus (2002), prior to the government's taking an official stance on it. In short, we see here an example of the feared costs faced by politicians in any conflict with the church.

These feared costs also go a long way towards explaining the status quo in general regarding church privileges within the constitutional framework. Meanwhile, on the part of the church, we have church leaders rely on and promote a religion-national identity link in efforts to maintain those privileges (including of course the financial benefits entailed). But of course, church attitudes and actions vary significantly according to the church hierarchy makeup, as we shall see below. 


\subsection{Agency - 1998-2008}

As far as church leaders go, Christodoulos' perspective on church-state relations was amongst his distinguishing markers. The Archbishop set the tone in his first month in the archbishopric - which, it should be noted, coincided with parliamentary discussions on the forthcoming constitutional revisions (including the question of a possible revision in church-state relations): he denounced 'those who want the shrinking of the church, because they know that the nation owes its existence to the church' (Alivizatos 1999). Indeed, a perennial theme throughout his period of influence was the necessary role played by the church, and by Greek Orthodoxy, in preserving the Greek nation. In fact, Christodoulos' voice on this theme in some cases was devoid of any mention of the church or of the Orthodox faith altogether; rather, he spoke as if on behalf of the Greek people as a whole. For example:

I worry about our national issues because I see that plans are being promoted which come into conflict with our rightly-understood national interests. We Greeks won our independence with sacrifice and blood and freed the parts of the so-called 'unredeemed' Hellenism. We cannot lose them today... (Christodoulos 2006)

This stance, together with his actions in the realm of politics (e.g., on the identity card issue), won Christodoulos a great deal of criticism. The critique is perhaps most acute in the aftermath of his death and in the transition to new church leadership. For brevity's sake, I will focus on the critique in the latter period, as expressed in the print media. 
According to one journalist, "most, friends and foe, recognised him as first a popular leader and second a religious leader' (Mandraveli 2008) ${ }^{11}$. The same perspective is evident in particular newspaper article titles: 'The intense statechurch relationship. Christodoulos took a stance on all major national and social issues, but avoided “touching” ecclesiastical issues' (Kambili 2008a); and "The end of a 10-year "war" (Kambili 2008b). According to one journalist, under Christodoulos the church 'presented an ethnocentric face, reigniting the schema of Helleno-Christianism, source of exploitation and trouble for many citizens in post-war history' (Ksidaki 2008).

Likewise, reporting on the newly elected Ieronymos' priorities frequently entailed implicit critique of Christodoulos: Ieronymos' stated focus on the repairing of relations with the Ecumenical Patriarchate reminded of Christodoulos' role in damaging them. And Ieronymos' tendency towards a synodal administration of the church, stating in his inaugural address that 'Christ is our leader and Christ said whoever wants to be first must be the servant of all', was described as 'not person-centric', suggesting the contrast with that under Christodoulos (Kalimeri 2008). One journalist draws the contrast more explicitly, reminding readers that Christodoulos' inaugural address was focused, instead, on exploring his role as Primate, the 'First' in the Greek Orthodox Church (Antoniadou 2008b).

\footnotetext{
${ }^{11}$ It should be noted that there were also a number of complementary newspaper articles. Amongst these is this particular newspaper article cited, as its author deems Christodoulos worthy of praise especially for locating the pulse of Greek society.
} 
Change introduced by Ieronymos is another recurrent theme in the newspaper coverage, where the term 'new page' factors prominently: 'the new page in the book of the Church of Greece seems that it will differ a lot from the previous one' (Antoniadou 2008b); 'the church, for 10 years, lived the dynamic but also exuberance of Christodoulos. Now, the hierarchy judged that the church had to move from the "I" to the "we" and to return to its synodal course, with a prudent, low-key (meaningfully so) archbishop at its head' (Kalokairinos 2008). His shunning of television cameras was especially striking to certain journalists: 'without clanging of cymbals and cameras the new archbishop of Athens changes the face of the Church of Greece. He brings it closer to Orthodox tradition of humility and love towards fellow human beings' ('The Church of the 21st Century' 2008). In an article entitled 'Mr. Ieronymos changes everything', the new situation is described in terms of television cameras being replaced by welfare concerns (Antoniadou 2008c). 'This is how we want the church', suggests one MP (Sifounaki 2008).

Special attention was paid, in the days following the election, to Ieronymos' perspective on church-state relations. Prefaced by a journalist's announcement that 'the views of the Archbishop have won the support of most of the political world', Ieronymos is cited in stating

We are not political but ecclesiastical men. We are first and necessarily agents and expressers of the prophetic gift of the priesthood. This means that the church has a duty to express its voice not in order to contest the institutions, or to get involved in policies 
and party disputes, but to express its anxiety when it feels that the degradation of morals and values undermines the future of the people of God [notably, not of the nation]... (Antoniadou 2008e).

To add weight to these words of the new archbishop, one journalist harkens back to Ieronymos' stance and statements whilst Metropolitan of Thebes, when he emphatically objected to what he called 'extremist activities' on the part of the church, stating that 'Church and state must find a different language of communication' (Kalimeri 2008b). Clearly, Ieronymos won many friends in the media for his church-state views, and introduced an element of hope that a significant change was taking place, one which might be mirrored by the state: '[Ieronymos] believes in distinctive roles, he follows them rigorously, but he demands the same of the other side' (Kalokairinos 2008).

Ieronymos' church-state perspectives were put to the test quite forcefully in his first weeks in the archbishopric, and in ways again indicating the complex interplay between the religion-nation link, church-state relations, and the role of agency. The first challenge came within days of his enthronement, in the form of another revival of 'the Skopiano' - the issue of the use of the name 'Macedonia' by Greece's former-Yugoslav neighbour. The Holy Synod, convening for the first time under Ieronymos, rebuffed the idea of a mass rally on the issue, calling for 'unity, consensus, maturity and prudence' ('Fears cloud crucial round' 2008). According to one newspaper article, 'The election of Ieronymos as Archbishop of Athens and All Greece is a spoke in the wheel of all those in the Holy Synod... who thought they could influence foreign policy' 
('Loyalists across the political spectrum' 2008). By 'those in the Holy Synod' the article means (and indicates) Metropolitan Anthimos of Thessaloniki, a champion in the 'Macedonia is Greek' campaign, who prior to the Holy Synod's aforementioned statement on the matter, had declared that there would 'definitely be one - two - good mass rallies' on the issue (Antoniadou 2008d). This was the first clear sign of major differences in opinion in the Holy Synod under the new archbishop.

The second challenge to Ieronymos' church-state perspectives - and, more poignantly, challenge to synodal unity - arose over the government's plans to introduce a cohabitation law. On 13 March 2008, Archbishop Ieronymos met with the Justice Minister, at the latter's request, in order to discuss the state's plans on the matter; the Minster was reportedly worried about a potential backlash from the church. The Archbishop's stated stance on the matter was in line with his aforementioned perspective on the place of the church in relation to the state and to politics:

There are clear limits and in respect to this matter, the church does not have the right to ask for it [the cohabitation law] to be watered down or to have any other request granted...Some people who have certain problems choose to regulate their lives in their own way. The church cannot keep a check on this by enforcing measures like the police ('Church clears cohabitation law' 2008).

The media, and politicians, received Ieronymos' response with surprise and relief (Antoniadou 2008e). 
Thus it came as a surprise to most observers when, three days later (17 March) the Holy Synod announced its opposition to the government's plan. More shocking still was the wording of the Synod's opinion, drafted - it should be noted - by Metropolitan Anthimos: 'The church accepts and blesses the established wedding, according to Orthodox traditions, and considers any other type of similar relationship to be prostitution' ('Church against cohabitation' 2008). Clearly, Ieronymos' perspective was not shared by all the Synod. Ieronymos reportedly accepted that the Synod's majority opinion on the draft law was negative, but was unaware of the wording of the Synod's official statement on the matter (see 'Ieronymos ire: Archbishop angry with wording' 2008). In his next Sunday sermon, Ieronymos called for a more tolerant church, suggesting that the church should be more open-minded and less moralizing: 'the church is what Christ wants it to be, not what people want it to be...We are giving the impression that the role of the church is to force people to be good' ('Ieronymos wants a more tolerant church' 2008). However, tension over the issue only heightened when the question arose whether the government would eventually extend the same legislation to homosexual couples, with Anthimos declaring that such a decision would degrade the human species and 'make them equal to animals' ('Letter from Thessaloniki' 2008) ${ }^{12}$.

Such tensions continue and many others are certain to arise. It should be clear, from this brief attention to the question of agency within the church during this

\footnotetext{
${ }^{12}$ It should be noted that months later, in his first address to a gathering of the full synod including all metropolitans of the Church of Greece (24 June 2008), Ieronymos delivered a solemn reflection on the synod's weaknesses in not having a truly synodal administration and being characterised instead by elements of autarchy. See Ieronymos (2008).
} 
limited time period, that there are vastly different perspectives amongst the church hierarchy on the place of the church in the public sphere, leading to vastly different actions on the part of the church in relation to the state.

The purpose of this reference to the historical and political context of Greek Orthodoxy has been to reveal the weaknesses behind generalised conceptions of Orthodoxy which point to organic links between religion and national identity, and between church and state. Far from organic, we have seen the links between religion and national identity as having developed within a very specific historical context, where political interests more than theology have influenced the shape of these links. Meanwhile, we have seen church-state relations built and perpetuated upon the latter contingent foundation, with de facto far more than de jure influences at play. Finally, a focus on the role of agency has shown two modes of church leadership with vastly different attitudes to the relationships between religion and national identity and between church and state; it has also drawn attention to divergences within the church hierarchy on these matters.

\section{Reassessing the place of religion in the Greek public sphere}

Church-state relations have been, and remain, a recurrent theme of discussion and debate in Greece. This discussion saw a renewed impetus with the election of a new archbishop. Shortly after Ieronymos' election, the newspaper To Vima ran a long piece entitled 'What should the role of the church be?' (10 February 
2008), where three scholars - Nikos Mouzelis, Michalis Stathopoulos, and Ioannis Konidaris - were invited to address the question.

For Mouzelis, the differentiation between church and state remains at very low levels in Greece. He describes the close intertwining of church and state functions, particularly during Christodoulos' reign, and argues that to some extent this has to do with the 'explosive, extremely ambitious personality of the Archbishop'. But it also has to do with the lack of institutional differentiation between the religious and the political spheres. His perspective on resolution of the problem is revealed in the title of his article: 'Necessary the separation from the state'. In this, he echoes an indeed familiar expression amongst many Greeks.

Stathopoulos' contribution, 'Faith and religious freedom' reads like a wish-list for the shape of the new church. The text outlines Stathopoulos' perspective on what the role of the church ought to be: it should open itself to society, but with an ecclesiastical voice, not a political one; it should be conciliatory and tolerant; it must reconcile itself with human rights; the church should avoid megalomanic behaviours and demagogy; it should avoid nationalistic exaltations; and - closing on that recurrent theme - it should discuss with the state the establishment, also in practice, of their distinctive roles.

For his part, Konidaris gives pause to reflect on the term 'distinctive roles'. In his contribution entitled 'The letter and the spirit [of the law]', he draws attention to the fact that since the end of the 1967-74 dictatorship, there has 
been a somewhat constant discussion of 'distinctive roles' of church and state. 'Political and ecclesiastical rulers tend to toy with it like candy in order to avoid the substance of the matter' - i.e., the specific definition of these terms and roles (Konidaris 2008a). Both sides draw the boundaries in different places, and so instead a superficial discussion continues, entailing a reiteration of the need to establish 'distinctive roles', but with no real efforts to delimit these.

Indeed, much of the discussion on the place of religion in the Greek public sphere focuses on the separation of, or distinct roles for, church and state. For Antonis Karkagiannis (Editor of Kathimerini newspaper), our conversation is misguided, and the critical question is 'who should separate from whom?' We mistake power with influence, he suggests: 'the influence of the ecclesiastical reality on the social body proceeds from the historic life, the spiritual lives, and deeper culture of the people'. Thus, by extension, decisions regarding religion's public place must resonate with the age-old conscience and the cultural foundations of the majority population'. With this in mind, Karkagiannis asks: are those calling for separation aiming at that of the church from the state, or rather of the church from the nation?' (Karkagiannis 2006).

Clearly, this is a poignant question, and it brings us to another dimension in the Greek debates on the place of religion in the public sphere - that questioning our conceptions of 'public' and 'private', which of course has implications for the place of religion in relation to the state or nation. Pantelis Kalaitzidis (2007) guides us adeptly through these debates. Making reference to a number of 
Greek scholars' (theologians and sociologists) writings on the subject, and also drawing on insights from philosophical discussions beyond the Greek context, Kalaitzidis opens the discussion by noting that 'the private is not antithetical to the social and the communal, and does not necessarily mean individual, but rather [it means] non governmental, and not related to state power'; meanwhile, the 'public' should not be confused with the 'state' (2007: 137). In fact, Kalaitzidis argues, we ought to maintain a perspective of three clear dimensions: the state, the public, and the private. Accordingly, he and other scholars he cites argue that beyond its place in the private sphere, religion, and the church, can and should have a public presence, since its natural space is society and specifically civil society. Following from Karkagiannis then, the argument is that it is a matter of fact that the church, in the Greek case, rightfully occupies a place in the public sphere, by virtue of the will of its majority population, in that religion is a public and not only a private issue. However, this can only be rightfully the case when:

a. the 'public' is distinguished from the state and the government (public being broader than both the latter);

b. the church's right to interference in the public sphere is subject to the terms and limits of that public sphere, including human rights; religious freedoms; tolerance of difference; and distinctive roles of church and state

c. the church's role in the public sphere does not also mean power in that space; nor does it mean the right to a voice on all issues in the public space (e.g., foreign policy; national issues; national identity; demographic problems, etc.) 
d. the church must understand its sphere of influence as not over 'the Greeks' in general, and its reference must not be to the national and patriotic community of the faithful but towards the eschatological, Eucharistic and hyper-ethnic community of the faithful (and the list goes on...).

But Kalaitzidis, echoing of course many other observers of the Greek Church, notes that this has not been the case in the Greek context. We cannot, in fact, have an intelligent discussion about the role of religion in the Greek public sphere, Kalaitzidis argues:

All this discussion cannot relate in a meaningful way to our church, as much as it will remain stubbornly and fearfully trapped in the form and the model of the constantinian period, to its state character and its nationalist-patriotic role [and] as long as it will stay...fixed to the model of the 'Christian society', of which it imagines it is spiritual ruler and sole representative, even in today's circumstances of pluralistic democracy. The dialogue on the place of the church in the public sphere concerns churches that have accepted modernity, pluralism, criticism and self criticism, and the principles of an open society, churches that perceive in a productive way the challenges, the gaps and the incontinences of post-modernity. Ours must finally decide in what world, in what society and in what era it lives! (Kalaitzidis 2007: 161)

In the extent to which this is the case, what is the reason for this state of affairs? It has been suggested above that the historical contingencies which led to a particular relationship between religion and national identity, and which 
underpinned the trajectory of Greek church-state relations, serve as a primary place to look to understand such trends.

For many, 'full separation of church and state' is an absolute necessity in Greece, not least for the reasons of removing barriers to the implementation of human rights and religious freedoms. However, there is also strong opposition to this point of view (Stavrakakis 2003). Certainly, church-state separation alone is not a panacea (Stavrakakis 2003). This much is clear in the fact that closer (on paper) church-state relations in other countries lead to fewer problems of religious rights limitations than in Greece. And indeed, as a notion 'full church-state separation' is in some ways arbitrary (the most 'secular' of states with strict church-state separation are thought to be the United States and France - both cases where, in fact, the entanglements of religion with policy are rather intricate. On this see Berger, Davie and Fokas 2008). At the same time, certainly formally eradicating the constitutional privileges enjoyed by the Greek Orthodox Church is a healthy starting point, one which could have a trickle-down effect into society in general.

But such measures would have to be accompanied by other efforts which will effectuate a long-term, but steady and coherent process of change - efforts focused on the aforementioned operative and combatable factors which (directly or indirectly) lead to limitations on religious freedoms and equality. For example, alteration of the way history is taught in schools and the place of religion and the church in this, thus helping lead to a better educated public less 
accepting of exploitations of church-state links; support for politicians risking political losses by resisting inappropriate interferences from the church, if and as they arise and, by the same token, some system of reprimand for those politicians who instead manipulate church-state links to their political benefit (something which will be much more conceivable if building upon the former suggestion re education of the public); and support for 'progressive' clergy who resist the banal and clichéd links between religion and nation, church and state and, rather, seek to cultivate the church's spiritual mission.

\section{Conclusion}

The current debates on the place of religion in the Greek public sphere come at an interesting moment in the trajectory of religion in the European public sphere, marked by lively discussion about the notion of a European 'secular neutrality'. On the one hand, we have popular literature voicing a hardline prosecularism (of which Richard Dawkins' The God Delusion is a most conspicuous piece), and on the other, an increasingly vocal, and proliferating, group of scholars criticising the secularist assumptions prevalent in the European context and in some cases, calling for a 'post-secular Europe', where religion has a legitimate place in the European public sphere (e.g., Jurgen Habermas (2006), Jose Casanova (2006), Francis Fukuyama (2006), William Connolly (2005), Charles Taylor (2007), Talal Asad (2003), Veit Bader (2007)). 
Such discussions rarely, if at all, address Orthodox contexts. Greece offers one example of a struggle over religion in the public sphere, one of course different from that in western Europe, where the focus is on secular neutrality and on whether space can and should be made for religion. But the overarching similarity is the significant fact of a state of flux around religion. In this context, what is needed is discussion as broadly based as possible on the distinctions between state, public, and private - incorporating also Orthodox contexts (not least given the eastward expansion of the European Union).

With this aim in mind, it is important to develop a firmer understanding of religion in Orthodox contexts, beyond the prevalent generalised perspectives addressed above. Even a superficial comparative approach to different Orthodox contexts introduces critical nuance, as differences begin to emerge between various majority and minority faith settings. Further, as demonstrated through a focused examination of the Greek case, the links between religion and national identity are very much contingent, so that assumptions about Orthodox norms in this case tend to be inaccurate and ahistorical. Meanwhile, church-state relations to a very large extent follow logically from the established (however contingent) religion-national identity links and, further, are shaped more by social rather than by either theological or even legal factors. And though it is too early in Ieronymos' role as archbishop to draw conclusions about significant changes being introduced, certainly by all available measures one can determine that the tone and approach of his 
leadership run counter to the popular stereotypes abounding about Orthodox churches.

This much should suffice at least as a starting point to re-focus our attention on actual factors at play behind the events and developments that lead to the stereotypes. On such a firmer basis, we are better prepared for an assessment of how to address problem areas (e.g. contesting the social, de facto influences, beyond the de jure realities). We are also thus better prepared for a constructive discussion on religion in the European public sphere, inclusive of Orthodox contexts. 


\section{References}

Alivizatos, N. (1999) 'A new role for the Greek Church?', Journal of Modern Greek Studies 17(1): 23-40.

Anagnostopoulou, S. (2000) 'The historicity of the "national role" of the Church of Greece', in Structures and Relations of Power in Contemporary Greece. Proceedings of the $7^{\text {th }}$ Scientific Conference, Panteion University, 21-24 Aug 1999, 349-352. Athens: Panteion. [In Greek]

Antoniadou, Maria (2000) 'Christodoulos from the pulpit: let there be a referendum for the new identity cards', To Vima, 15 May, p. A3. [In Greek]

-- (2008a) 'The first message of the Archbishop', To Vima 9 February. Accessible at http://www.tovimadaily.gr/Article.aspx?d=20080209\&nid=7426639 [In Greek]

-- (2008b) 'All the Archbishop's Men', To Vima 10 February, p. A18. [In Greek]

-- (2008c) 'Mr. Ieronymos changes everything', To Vima 17 February, p. A18. [In Greek]

-- (2008d) 'Metropolitan of Thessaloniki Anthimos. Certainly one-two good mass rallies', To Vima 24 February, p. A13. [In Greek]

-- (2008e) 'Mr. Ieronymos began (and will continue) the reforms' To Vima 16 March, p. A40. [In Greek]

Asad, Talal (2003) Formations of the Secular: Christianity, Islam, Modernity, Stanford: Stanford University Press.

Bader, V.M. (2007) Secularism or democracy? Associational governance of religious diversity (IMISCOE Research), Amsterdam: Amsterdam University Press.

Berger, Peter (1999) 'The Desecularization of the World', in ed. P.Berger, The Desecularization of the World: Resurgent Religion and World Politics, Peter Grand Rapids, Michigan: William B. Eerdmans Publishing Company, pp.1-18.

Berger, Peter, Grace Davie and Effie Fokas (2008) Religious America, Secular Europe? A theme and variations, London: Ashgate (forthcoming).

Byrnes, T. (2006) 'Transnational religion and Europeanization', in ed. T.Byrnes and P.Katzenstein, Religion in an Expanding Europe. Budapest: Central European University Press, pp. 283-305.

Casanova, José (2006) 'Religion, European Secular Identities and European Integration', in ed. K.Michalski, Religion in the New Europe. Budapest: Central European University Press, pp. 23-44.

Christodoulos (former Archbishop of Athens and all Greece) (1997) 'Hellenism and Europe', To Vima, 19 January, p. A17. 
-- (2006) 'Interview of the Archbishop' Kosmos tou Ependiti 8 July. [In Greek]

'The Church of the $21^{\text {st }}$ century' (2008) Kathimerini 14 March. [English language website http://www.ekathimerini.com/4dcgi/_w_articles_columns_2_14/03/2008_94403]

'Church clears cohabitation law' (2008) Kathimerini 14 March. [English language website edition: http://www.ekathimerini.com/4dcgi/_w_articles_politics_2_14/03/2008_94409]

Clark, Bruce (2004) Unpublished text drafted as a preamble to a proposed symposium on "Orthodoxy and the Future of Europe."

Clogg, Richard (ed.). (2002) Minorities in Greece: Aspects of a Plural Society, London: Hurst and Co.

Connolly, William (2005) Pluralism. Durham: Duke University Press.

Danopoulos, Constantine (2004) 'Religion, civil society, and democracy in Orthodox Greece', Journal of Southern Europe and the Balkans 6(1): 41-55.

Demertzis, N. (1996) 'La place de la religion dans la culture politique grecque', in ed. S.Mappa, Puissance et Impuissance de l'Etat: les Pouvoirs en Question en Nord et au Sud, Paris: Karthala, pp.233-244.

Dimitropoulos, P. (2001) State and Church: a Difficult Relationship. Athens: Kritiki. [In Greek]

'Fears cloud crucial round of name talks' (2008) Kathimerini 29 February [English languge website edition: http://www.ekathimerini.com/4dcgi/_w_articles_politics_2_29/02/2008_93908 ]

Fokas, Effie (2006) 'Greece: religion, nation, and membership in the European Union', in ed. H.Gulalp, Citizenship and ethnic conflict: challenging the nationstate, London: Routledge, pp. 39-60.

-- (2008) 'Religion: towards a post-secular Europe?', in ed. C.Rumford, Sage Handbook on European Studies, London: Sage (forthcoming).

Fukuyama, Francis (2006) 'Identity, Immigration and Liberal Democracy', Journal of Democracy 17(2): 5-20.

Georgiadou, V. (1995) 'Greek Orthodoxy and the politics of nationalism', International Journal of Politics, Culture and Society 9(2): 295-315.

Habermas, Jürgen (2006) 'Religion in the Public Sphere', European Journal of Philosophy 14(1): 1-25.

Ieronymos (Archbishop of Athens and all Greece) (2008) 'Proposal of His Beatitude Archbishop of Athens and all Greece Mr. Ieronymos at the Convocation of the 
Hierarchy (24-06-08)'. Available online at http://www.ecclesia.gr/greek/archbishop/default.asp?cat_id=\&id=685\&what_mai $\underline{\mathrm{n}=1 \& \text { what_sub=23\&lang=gr\&archbishop_who=2\&archbishop_heading=Eı } \sigma \eta \eta \dot{\sigma} \sigma}$ sis [In Greek]

'Ieronymos ire. Archbishop angry with wording of Synod response to cohabitation law' (2008) Kathimerini 19 March. [English language website edition: http://www.ekathimerini.com/4dcgi/_w_articles_politics_2_19/03/2008_94587]

'Ieronymos wants a more tolerant church' (2008) Kathimerini 24 March [English language website edition: http://www.ekathimerini.com/4dcgi/_w_articles_politics_2_24/03/2008_94712]

Kalaitzidis, Pantelis (2007) Orthodoxy and Modernity: Prologue, Athens: Indiktos. [in Greek]

Kalimeri, Xara (2008a) 'Change of page in the church' Hmerisia 8 February [accessed online: http://www.imerisia.gr/article.asp?catid=12305\&subid=2\&PubID=901154\&word $=\% \mathrm{C} 9 \% \mathrm{E} 5 \% \mathrm{~F} 1 \% \mathrm{FE} \% \mathrm{ED} \% \mathrm{~F} 5 \% \mathrm{EC} \% \mathrm{EF} \% \mathrm{~F} 5$ ] [In Greek]

-- (2008b) "The "dogma" of Ieronymos for changes in the church' Hmerisia 9 February [accessed online: http://www.imerisia.gr/article.asp?catid=12305\&subid=2\&PubID=901275\&word =\%C9\%E5\%F1\%FE\%ED\%F5\%EC\%EF\%F5 ] [In Greek]

Kalokairinos, Grigoris (2008) 'Why the Hierarchy chose Ieronymos as Archbishop' To Vima 17 February, p. A20. [In Greek]

Kambili, Taki (2008a) 'The intense church-state relation. Christodoulos took a stance on all major national issues, but avoided 'touching' the ecclesiastical issues' Kathimerini 3 February. Accessible at: http://news.kathimerini.gr/4dcgi/_w_articles_politics_1_03/02/2008_257999 [In Greek]

-- (2008b) 'The end of a decade of "war" Kathimerini 8 February. Accessible at: http://news.kathimerini.gr/4dcgi/_w_articles_politics_2_08/02/2008_258591 [In Greek]

Karkagiannis, Antonis (2006) 'Church and state (but also church and ethnos?)' Kathimerini 15 January. Accessible at: http://news.kathimerini.gr/4dcgi/_w_articles_columns_1_15/01/2006_170080 [In Greek]

Kishkovsky, Leonid (2004) 'Orthodoxy in America: Diaspora or Church?' Accessible online at http://www.orthodoxytoday.org/articles4/KishkovskyDiaspora.php

Kokosalakis, Nikos (1987) 'Religion and modernization in $19^{\text {th }}$ century Greece', Social Compass, 34(2/3): 223-242. 
-- (1995) 'Greek Orthodoxy and modern socio-economic change', in ed. R.Roberts, Religion and the Transformation of Capitalism, London: Routledge, pp.248-265.

-- (1996) 'Orthodoxie grecque, modernité et politique', in eds. G.Davie and D.HervieuLéger, Identités religieuses en Europe, Paris: La Découverte, pp.131-151.

-- (1997) 'Orthodoxy and social change in modern Greek society', in Synaksi, Issue 62, pp.101-108. [in Greek]

Konidaris, Ioannis (2003) 'The legal parameters of church and state relations in Greece', in eds. T.Couloumbis, T.Kariotis, and F.Bellou, Greece in the Twentieth Century, London: Frank Cass, pp.223-235.

-- (2008) 'The letter and the spirit [of the law]' To Vima 10 February, p.B22. [In Greek]

Ksidaki, Nikos (2008) 'Economy [oikonomia] and love' Kathimerini 10 February Accessible online at: http://news.kathimerini.gr/4dcgi/_w_articles_columns_2_10/02/2008_258862

'Letter from Thessaloniki. Puritans and progressive clergy' (2008). Kathimerini 31 March [English language website edition: http://www.ekathimerini.com/4dcgi/_w_articles_columns_2_31/03/2008_94921]

'Loyalists across the political spectrum' (2008) Kathimerini 3 March [English language website edition: http://www.ekathimerini.com/4dcgi/_w_articles_ell_2_03/03/2008_93981]

Mandraveli, Pasxou (2008) 'The legacy of Christodoulos' Kathimerini 3 February. Accessible online at: http://news.kathimerini.gr/4dcgi/_w_articles_columns_1_03/02/2008_257970. [In Greek]

Manitakis, A. (2000a) 'The Autocephalous Church of Greece between State and Nation', in Structures and Relations of Power in Contemporary Greece, Proceedings of the $7^{\text {th }}$ Scientific Conference, Panteion University, 21-24 Aug 1999, Athens: Panteion, pp. 327-342. [In Greek]

-- (2000b) The Relations of the Church with the Nation-State, Athens: Nefeli. [in Greek]

Martínez-Torrón, Javier and Rafael Navarro-Valls (2004) 'The Protection of Religious Freedom in the System of the Council of Europe.' In Facilitating Freedom of Religion and Belief: A Deskbook edited by T. Lindholm, C. Durham and B. Tahzib-Lie. Leiden: Martinus Nijhoff, pp.209-238.

Molokotos-Liederman, L. (2007) 'The Greek ID cards controversy: a case study on religion and national identity in a changing European Union', Journal of Contemporary Religion 22(2): 187-203.

Mouzelis, Nikos (2008) 'Necessary the separation from the state' To Vima 10 February, p. B20. [In Greek] 
Paparizos, A. (1998) 'Du caractère religieux de l'etat grec moderne', 'Ilu revista de ciencias de las religiones, No.3, pp.183-207.

Papastathis, C. (1996) 'State and church in Greece', in ed. G.Robbers, State and Church in the European Union, Baden-Baden: Nomos Verlagsgesellschaft, pp. 75-92.

Payne, Daniel (2003) 'The Clash of Civilisations: the Church of Greece, the European Union and the Question of Human Rights', Religion, State and Society 31(3): 261-271.

Pollis, A. (1993) 'Eastern Orthodoxy and Human Rights', Human Rights Quarterly 15(2): 339-352.

-- (2003) 'Greece, a problematic secular state', in ed. W.Safran, The Secular and the Sacred: Nation, Religion and Politics, London: Frank Cass, pp.155-168.

Prodromou, Elizabeth (1993) 'Democracy, Religion and Identity in Socialist Greece: Church-State Relations under PASOK, 1981-1989', unpublished PhD thesis, MIT.

Ramet, Sabrina (2006) 'The way we were - and should be again? European Orthodox Churches and the "idyllic past", in ed. T. Byrnes and P.Katzenstein, Religion in an Expanding Europe, New York: Cambridge University Press, pp. 148-176.

Sifounaki, Nikos (2008) 'This is how we want the church' Eleutherotypia 10 February Accessible online at: http://www.enet.gr/online/online hprint?q=\%C5\%EA\%EA\%EB\%E7\%F3\%DF\% $\underline{E} 1 \& a=\& i d=80373464$.

Stathopoulos, Michalis (2008) 'Faith and religious freedom' To Vima 10 February, p. B22. [In Greek]

Stavrakakis, Yannis (2003) 'Politics and Religion: on the "Politicization" of Greek Church Discourse', in Journal of Modern Greek Studies 21(2): 153-181.

Stavrou, T. (1995) 'The Orthodox Church and political culture in Greece', in eds. D.Constas and T.Stavrou, Greece Prepares for the Twenty-first Century, Washington, D.C.: Woodrow Wilson Center Press, pp. 35-54.

Taylor, Charles (2007) A Secular Age, Cambridge, Mass: Harvard University Press.

Vassiliadis, Petros (2003) 'Orthodox Christianity', in ed. J.Neusner, God's Rule, Washington, D.C.: Georgetown Univ. Press., pp. 85-106.

Veremis, Thanos (1989) 'From the National State to the Stateless Nation, 1821-1919', European History Quarterly 19(2): 135-148.

Yiannaras, Christos (1976) Chapters of Political Theology, Athens: Papazisi. [In Greek] 



\section{Other papers in this series}

Fokas, Effie, A new role for the church? Reassessing the place of religion in the Greek public sphere, GreeSE Paper No17, August 2008

Klapper, Leora and Tzioumis, Konstantinos, Taxation and Capital Structure: evidence from a transition economy, GreeSE Paper No16, July 2008

Monastiriotis, Vassilis, The Emergence of Regional Policy in Bulgaria: regional problems, EU influences and domestic constraints, GreeSE Paper No15, June 2008

Psycharis, Yannis, Public Spending Patterns:The Regional Allocation of Public Investment in Greece by Political Period, GreeSE Paper No14, May 2008

Tsakalotos, Euclid, Modernization and Centre-Left Dilemmas in Greece: the Revenge of the Underdogs, GreeSE Paper No13, April 2008

Blavoukos, Spyros and Pagoulatos, George, Fiscal Adjustment in Southern Europe: the Limits of EMU Conditionality, GreeSE Paper No12, March 2008

Featherstone, Kevin, 'Varieties of Capitalism' and the Greek case: explaining the constraints on domestic reform?. GreeSE Paper No11, February 2008

Monastiriotis, Vassilis, Quo Vadis Southeast Europe? EU Accession, Regional Cooperation and the need for a Balkan Development Strategy, GreeSE Paper No10, January 2008

Paraskevopoulos, Christos, Social Capital and Public Policy in Greece. GreeSE Paper No9, December 2007

Anastassopoulos George, Filippaios Fragkiskos and Phillips Paul, An 'eclectic' investigation of tourism multinationals' activities: Evidence from the Hotels and Hospitality Sector in Greece, GreeSE Paper No8, November 2007

Watson, Max, Growing Together? - Prospects for Economic Convergence and Reunification in Cyprus, GreeSE Paper No7, October 2007

Stavridis, Stelios, Anti-Americanism in Greece: reactions to the 11-S, Afghanistan and Iraq, GreeSE Paper No6, September 2007

Monastiriotis, Vassilis, Patterns of spatial association and their persistence across socio-economic indicators: the case of the Greek regions, GreeSE Paper No5, August 2007

Papaspyrou, Theodoros, Economic Policy in EMU: Community Framework, National Strategies and Greece, GreeSE Paper No4, July 2007

Zahariadis, Nikolaos, Subsidising Europe's Industry: is Greece the exception?, GreeSE Paper No3, June 2007

Dimitrakopoulos, Dionyssis, Institutions and the Implementation of EU Public Policy in Greece: the case of public procurement, GreeSE Paper No2, May 2007

Monastiriotis, Vassilis and Tsamis, Achilleas, Greece's new Balkan Economic Relations: policy shifts but no structural change, GreeSE Paper No1, April 2007

Other papers from the Hellenic Observatory

Papers from past series published by the Hellenic Observatory are available at http://www.lse.ac.uk/collections/hellenicObservatory/pubs/DP_oldseries.htm 